\title{
BETUTU BALI \& MENUJU KULINER DIPlomasi budaya INDONEsIa
}

\section{BETUTU OF BALI: TOWARDS INDONESIAN CULINARY DIPLOMACY}

\author{
I Made Purna dan Kadek Dwikayana \\ Balai Pelestarian Nilai Budaya Bali \\ Jl. Raya Dalung No.107, Dalung, Kec. Kuta Utara, Kabupaten Badung, Bali 80351 \\ e-mail: purna.bpsntbali@gmail.com,dwikadecka@gmail.com \\ Naskah Diterima:20 Desember $2018 \quad$ Naskah Direvisi:30 Januari 2019 Naskah Disetujui: 28 Juni 2019
}

DOI: $10.30959 /$ patanjala.v11i2.478

\begin{abstract}
Abstrak
Etnis Bali yang beragama Hindu, telah memiliki sumber daya budaya berupa kuliner tradisional betutu dari bahan ayam dan bebek. Kuliner betutu dimasak dengan bumbu "jangkep" (lengkap). Kuliner ini pada awalnya difungsikan sebagai makanan persembahan terhadap Ida Hyang Widhi Wasa/Tuhan Hyang Maha Esa, dan hasil persembahannya disantap bersama-sama. Namun, perkembangan selanjutnya difungsikan sebagai hidangan kaum raja-raja dan keluarganya, dan kebutuhan sosial. Dalam menghadapi politik global dan pariwisata, maka Betutu difungsikan sebagai kebutuhan biologis anggota masyarakat secara umum, pariwisata dan diplomasi. Tujuan dari penulisan artikel ini (1) melestarikan kuliner Betutu Bali (2) mempopulerkan kuliner Betutu sebagai media identitas, toleransi (kerukunan, keharmonisan) antar umat beragama, etnis dan bangsa. Artikel ini menggunakan konsep kuliner, gastro diplomasi dan teori fungsional. Metode yang digunakan dalam penelitian ini menggunakan metode kualitatif deskriptif dengan teknik sampling menggunakan purposive sampling dan snowball sampling. Hasil penelitian ini menunjukkan kuliner Betutu dapat diterima oleh semua kalangan dengan terbukti dapat ditemukan atau disajikan di hotel-hotel berbintang, restauran, dijual di warung-warung makanan dengan omset yang selalu meningkat.
\end{abstract}

Kata kunci:betutu, kuliner, diplomasi, toleransi.

\section{Abstract}

Hindus Balinese ethnic has cultural resources in the form of betutu, a traditional culinary from chicken and duck. Betutu is cooked with "jangkep" (complete) spices. This food was originally functioned as a food offering to Ida Hyang Widhi Wasa (Hyang the One God), and the results of her offerings were eaten together. However, further developments functioned as a dish for the kings and their families, and social needs. In the face of global politics and tourism, Betutu functioned as the biological needs of community members in general, tourism and diplomacy. The purpose of writing this are (1) preserving Betutu Bali culinary (2) popularizing Betutu culinary as a medium of identity, tolerance (harmony) between religious and ethnic groups. This article uses concepts such as culinary, gastro diplomacy and functional theory. This study uses descriptive qualitative methods with sampling techniques like purposive sampling and snowball sampling. The results of this study show that Betutu culinary can be accepted by all people, proven to be found or served in starred hotels, restaurants, sold in food stalls with an ever-increasing turnover.

Keywords: betutu, culinary, diplomacy, tolerant.

\section{A. PENDAhULUAN}

Makanan adalah objek yang selalu ada dalam masyarakat. Makanan merupakan benda umum yang komunal sepanjang sejarah. Dahulu kala, makanan sekadar objek dari suatu simbol yang diartikan untuk mempertahankan hidup. Bahkan makanan hanya untuk menghilangkan rasa lapar atau untuk memenuhi hasrat perut besar (gaster) yang 
kosong, sehingga ada dua kata yang berhungan dengan makanan sebelum dan sesudah makan yaitu kata "lapar" dan "kenyang". Tidak ada yang melihat dari segi komposisi gizi, jumlah karbohidrat, maupun kandungan vitamin, protein, alat politik dan lain-lain. Bagi orang yang terbatas penyediaan sumber makanan sering menyampaikan ungkapan "makan apa hari ini agar bisa bekerja (hidup)". Perkembangan selanjutnya, makanan telah memiliki arti lebih, yaitu berfungsi sosial religius dan menunjukkan identitas budaya. Maka, kata makanan mengalami perkembangan istilah, yaitu menjadi "kuliner" yang artinya "the art of good cooking", yakni seni persiapan, hasil olahan dan presentasi penyajian masakan yang dilakukan oleh chef profesional atau ahli masak otodidak ("pemasak" atau "koki" atau"juru masak"). Hal ini menjadikan kuliner mampu menciptakan sebuah karakter sosio-antropologis dan spiritual bagi masyarakat pendukungnya. Karena kuliner merupakan suatu hasil kebudayaan dan merupakan identitas budaya lokal (Yudha, 2015 : 334).

Oleh karena makanan sudah mengalami perkembangan cara pandang, maka semenjak tahun 1900, makanan mulai dikaji para akademisi yang kontribusinya sangat signifikan, terutama bagi disiplin ilmu politik yang mulai memperkenalkan isu makanan sebagai basis ilmu politik untuk kelangsungan dan proliferasi dari sebuah negara dan bangsa yang modern. Bahkan tidak jarang prestise kekuatan suatu negara para politikus yang sedang berkuasa menggunakan makanan sebagai kekuatan diplomasi sebagai tindakan berstrategi, taktik, dan siasat untuk mencapai tujuannya, di samping keramahtamahan budaya yang dimiliki. Apalagi dalam materi pertemuan diplomasi ada kesenjangan cara pandang, maka perlu langkah pengorganisasian, lobi dan negosiasi dalam menyelesaikan perbedaan atau menyamakan (memperkuat) persamaan posisi lawan bicara. Diplomasi adalah soft power yang menandakan kekuatan nasional atau suatu negara dalam nilai-nilai global yang menggunakan outlet yang dipilih untuk mencapai tujuannya. Penggunaan makanan sebagai brand atau trademark suatu bangsa adalah salah satu alat khusus dari segi pemerintah, yang digunakan secara luas dan lebih kuat dibandingkan penggunaan diplomasi budaya dalam arti seni tari maupun musik.

Untuk memposisikan ide tersebut di atas maka lahirlah "Gastronomi Diplomasi", yaitu diplomasi melalui makanan atau dalam bahasa antarbangsa "Gastronomi Diplomacy". Dewasa sekarang Gastro-Diplomasi dipandang oleh Paul Rockower (dalam Indra Keteran, indraket@gmail.com, diakses tanggal 27/11/2016), sebagai tindakan memenangkan hati dan pikiran melalui perut. Di samping memang makanan dianggap sebagai tindakan pengenalan lintas budaya dengan harapan mewujudkan interaksi dan kerjasama pada level pemerintah ke pemerintah yang lebih tinggi.

Pada etnis Bali yang mayoritas beragama Hindu dan juga minoritas beragama selain hindu seperti Kristen, Islam, Budha. Mempunyai kebiasaan sebagai adat kulinernya masakan ayam betutu, tadinya termasuk jenis makanan yang didominasi oleh etnis Bali beragama Hindu saja karena masuk dalam sesajian dalam upacara agama Hindu, tetapi sekarang sudah menyebar pada semua latar belakang agama selain hindu. Betutu sudah mendapat penetapan sebagai Warisan Budaya Takbenda (WBTB) Indonesia. Karena itu, kuliner betutu perlu ditingkatkan fungsinya sebagai sarana diplomasi. Sebagai sarana diplomasi dapat dimaklumi karena kuliner ini dianggap sebagai kuliner yang paling netral dan halal (bukan haram bagi kelompok agama tertentu), untuk mewujudkan persaudaraan, kerukunan antarumat beragama. Asal usul kata betutu yaitu, be artinya daging, atau ikan. Sedangkan kata tutu dari kata tunu, yang artinya dibakar atau dipanggang. Seperti juga kata tunon dari kata tunu 
khusus untuk pembakaran mayat pada upacara ngaben. Tempat pembakaran mayat (setra) di Bali, juga disebut tunon. Betutu dimasak memakai bumbu lengkap (genep/jangkep) yang terdiri atas, bawang merah, bawang putih, cabe merah, cabe rawit, kemiri, kencur, lengkuas, jahe, kunyit, daun jeruk purut, ketumbar, pala, merica, gula aren, garam, terasi ditumis dan dihaluskan, dan base wange, serta minyak kelapa. Teknik pembuatan betutuadalah langsung ditunu (dibakar) di atas atau dipendam dalam api sekam dan ada pula dibeberapa tempat di Bali terlebih dahulu dimasak dengan air yang dilengkapi dengan bumbu jangkep, kemudian ditunu (dibakar) di atas bara api. Daging yang dipakai bahan yaitu daging ayam, baik ayam kampung maupun ayam petelur (ras) dan boiler serta bebek.

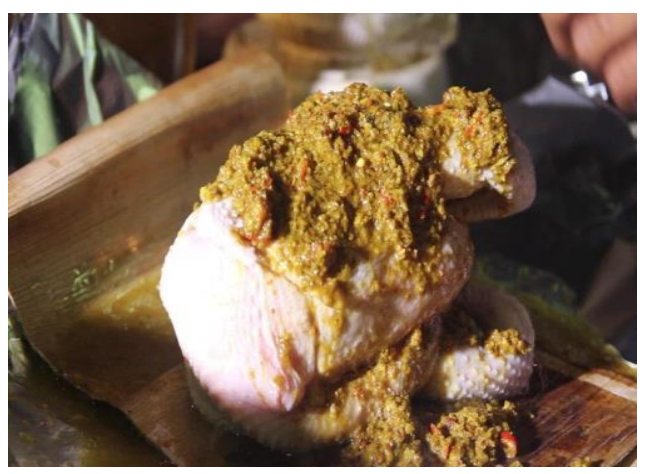

Gambar 1. Membumbui daging ayam dengan bumbu jangkep yang sudah dihaluskan. Sumber: Purna, 2016.

Pada awalnya jenis kuliner betutu dikenal di daerah Gianyar. Namun saat ini semua etnis Bali yang beragama Hindu mengenalnya. Bahkan sekarang hampir semua etnis, agama maupun bangsa yang tinggal di Bali sudah mengenal dan merasakan betutu. Betutu sekarang merupakan kuliner andalan di seluruh Bali. Pada tahun 1976 betutu ayam dan bebek dibuat oleh MenTempeh atau Ni Wayan Tempeh yang berasal dari Abianbase, Gianyar. Jenis betutu yang dibuat dikomersialkan. Sedangkan betutu yang dipakai sarana upacara di Bali sudah dikenal cukup lama. Namun bahan dagingnya hanya ayam kampung (Suarsana dkk., 2016). Oleh karena betutu sudah mengalami perkembangan dan pengenalannya sudah masuk dalam barisan masakan Nusantara. Karena itu, tidak mengherankan, Indra Keteran, sebagai seorang ahli gastronomi Indonesia, kuliner betutu dipandang sebagai kuliner titik pembatas antara jenis masakan Indonesia bagian barat dan Indonesia bagian timur (https://groups.google.com/d/msgid/gastro nomi-indonesia, diakses 11/01/2016).

Dari uraian tersebut di atas, maka dapat dirumuskan permasalahan yang akan dikaji sebagai berikut: 1) Apa fungsi diplomasi betutu terhadap masyarakat Bali; 2) Dapatkah betutu Bali dijadikan kuliner diplomasi antara pemeluk agama, etnis dan bangsa. Sedangkan tujuan dari penulisan artikel ini antara lain : 1) Melestarikan kuliner betutu Bali. 2) Mempopulerkan kuliner betutuBali sebagai kuliner media toleransi, dan diplomasi (kerukunan, keharmoinisan) antarumat beragama, etnis dan bangsa.

Sebelum membahas kuliner betutu sebagai diplomasi hubungan ke dalam, dan diplomasi keluar, terlebih dahulu akan dideskripsikan mengenai garis pemetaan atau garis pembatas sebagai sumber kekuatan yang dimiliki makanan tradisonal betutu. Betutu secara geografis Nusantara sebetulnya dijadikan "Garis Seni Masakan", yang menandakan perubahan makanan dari kepulauan-kepulauan yang ada di Indonesia. Menurut Ensiklopedi Suku Bangsa di Indonesia, bahwa di setiap daerah masing-masing suku bangsa yang jumlahnya 714 suku bangsa (Melalatoa, 1995), telah memililki ciri khas makanan tradisionalnya, baik itu makanan berat, maupun ringan, atau sekadar minuman. Untuk Indonesia bagian barat (Sumatra), masakan Melayu memegang peranan penting. Karena kentalnya percampuran budaya Melayu, India, dan Timur Tengah, makanya cenderung pedas, berlemak, dan kuat dalam penggunaan rempah-rempah. Ciri khas utamanya adalah makanan berkuah berbasis santan yang disebut gulai. 
Dari Sumatra, pengaruhnya masih terasa sampai di Kepulauan Sunda dan Jawa.

Namun di Pulau Jawa rasanya tidak mengandalkan lemak kelapa, tetapi tarikannya lebih cenderung manis. Orang Jawa rupanya lebih suka tarikan rasa manis daripada Sumatra, sehingga banyak teknik masakan dan bahan seperti kecap yang membawa citarasa makanan menjadi manis. Orang Sunda di Jawa Barat makanannya lebih cenderung natural saja, seperti lalapan, tempe, tahu, dan sambal.

Makin ke timur Pulau Jawa seperti di Solo, Jogya, makin kentara rasa manis. Sampai-sampai kalau pesan minuman pasti disajikan manis. Mereka menganggap tidak masuk akal minum yang tidak manis. Apabila bergerak ke timur pulau Jawa, terlihat di Jawa Timur punya rasa yang lain. Di sini rasanya sudah mulai tajam, misalnya dengan kehadiran petis. Dibandingkan di Jawa Tengah, rasa manis sudah berkurang, diganti dengan rasa pedas dan tarikan sedikit asam. Ini menunjukkan pengaruh Melayu sudah mulai berkurang, diganti pengaruh Timur.

Lompat dari Pulau Jawa ke Pulau Bali, ada sebuah lonjakan besar dalam cita rasa. Oleh karena itu, diantara Kepulauan Jawa dan Bali inilah "Garis Seni Masakan" yang ada di Nusantara. Pada titik inilah batas tarikan rasa Indonesia bagian barat dan timur yang punya celah secara antropologis hubungan kuat antara seni masakan orang Bali dan Jawa. Makanan Bali menjadi berbeda dengan makanan Jawa. Satu tandanya, bahwa masakan Bali berbeda dengan Jawa dapat dilihat dari betutu. Pada masakan betutu lebih mencerminkan dari bumbu masakan Jawa Kuno. Cirinya pada bumbu yang mirip dengan jamu. Unsur santannya sudah nyaris tidak ada. Kalaupun ada santan namun fungsinya tidak sebagai kuah, namun sebagai bumbu. Untuk rasanya, bumbu-bumbu yang digunakan lebih tajam aromanya. Jenis metode ini dibawa oleh penduduk dan bangsawan Majapahit yang berpindah ke Bali dahulu pada saat terdesaknya agama Hindu oleh agama
Islam di Pulau Jawa. Oleh karena itu, tidak mengherankan kalau betutu yang dijadikan sampel kajian untuk memperkuat keberadaan inventarisasi Warisan Budaya Takbenda dari Pulau Bali yang berlokasi di Desa Peliatan, Gianyar. Di tempat ini ditemui asal-usul skil yang dimiliki oleh keluarga Bapak Neka, anggota keluarga maupun para pendukungnya berasal dari Puri Peliatan. Demikian kompleks dan panjang sejarahnya betutu yang ada di Bali.

Pendekatan yang digunakan untuk menganalisis keberadaan betutu yang ada di Bali dengan menggunakan pendekatan fungsional yang dikemukakan oleh Malinowski, yang memahami masyarakat melalui kebudayaan. Pendekatan ini muncul didasari oleh pemikiran dan tindakan orang sekitarnya, sehingga manusia tidak pernah mampu sepenuhnya menetukan pilihan tindakan, sikap, atau perilaku tanpa mempertimbangkan orang lain. Lebih jauh Malinowski mengemukan bahwa semua unsur kebudayaan merupakan bagian terpenting dalam masyarakat. Karena itu, setiap pola adat kebiasaan, termasuk makanan tradisi merupakan bagian dari fungsi dasar dalam kebudayaan. Masyarakat dapat dikatakan sebagai sistem sosial yang di dalamnya terdiri atas bagian-bagian yang saling berhubungan dalam rangka pemenuhan kebutuhan dasarnya, seperti makanan, istirahat, perlindungan, kepuasan seksual, serta kebutuhan sekunder, seperti komunikasi, koperasi, pengawasan, penyelesaian konflik, dan sebagainya. Kepuasan kebutuhan sekunder akan mengembangkan bahasa, norma, aturan dan menguatkan setiap bagian yang pada gilirannya akan meningkatkan koordinasi, pengaturan, dan pengintegrasian lembagalembaga (Sulasman dan Gumilar, 2013).

Dalam tulisan Edi Sedyawati (2014: 309-311), tentang makanan dan kebudayaan, mengemukakan bahwa, dalam setiap kebudayaan makanan/boga sering kali diberi beberapa makna yang khusus, terkait dengan berbagai fungsi 
dalam kehidupan manusia. Pemaknaan makanan dapat terkait dengan struktur sosial, sistem religi, dan tentu juga terkait dengan sistem ekonomi maupun dunia pariwisata dan konsep keperawatan diri dalam masing-masing satuan sosial pendukung suatu kebudayaan. Dengan demikian, dalam konteks suatu kebudayaan suku bangsa, pada umumnya makanan tidak pernah semata-mata hanya sebagai pasokan gizi dan nutrisi untuk pertahanan kehidupan jasmaniah. Melainkan ada juga nilai-nilai budaya yang terkait dengannya. Bahkan dalam hubungan dengan dunia luar makanan bisa dijadikan sarana diplomasi antar bangsa, antar negara dan antarpemeluk agama, dan etnis yang berbeda. Apakah nilai budaya yang berkaitan dengan hubungan manusia dengan Maha Pencipta, hubungan antarmanusia dengan manusia, dan hubungan manusia dengan lingkungan alam. Namun yang lebih penting lagi, bahwa makanan tradisional dapat digunakan sebagai sarana untuk mencapai ketahanan pangan, diversifikasi makan. Karenanya makanan juga merupakan satu di antara jenis-jenis kearifan lokal dari suku bangsa yang bersangkutan (Sunjata, 2014).

Betutu merupakan satu di antara makanan pokok kebutuhan dasar suku bangsa (etnis) Bali, dalam rangka pelestariannya tergantung pada kemampuan orang Bali untuk membina hubungan timbal balik (adaptation) dengan lingkungan hidupnya. Etnis Bali pada saat ini membina hubungan dengan betutu secara aktif dan dinamis, terutama yang berkaitan dengan aspek ekonomi dan pariwisata. Oleh sebab itu tidak mengherankan ada jenis-jenis penamaan, dan teknik atau cara maupun proses pengolahan betutu yang dikenal di Bali. Ada namanya Betutu Rama, Betutu Gilimanuk, Betutu Men Tempeh, Betutu Liku, Ayam Betutu Kedewatan, dan lainlain. Sedangkan teknik atau cara atau proses pengolahan ada yang dibakar (tunu) dan ada yang direbus. Kedua cara ini merupakan teknik atau cara atau proses baku dalam pengelolaan makanan tradisional dalam kebudayaan suku bangsa di Indonesia, selain dijemur.

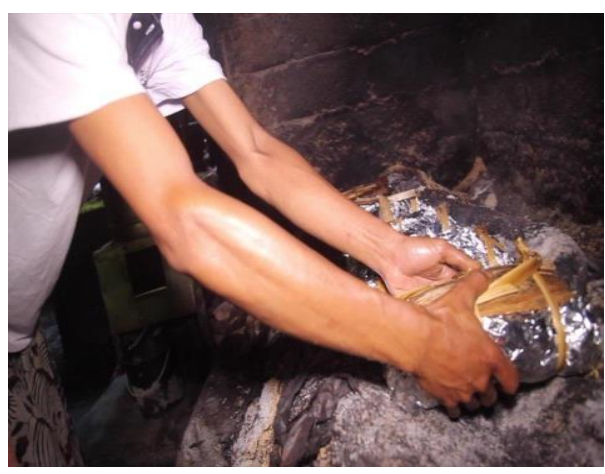

Gambar 2. Memasukkan betutu mentah ke dalam bara api sekam. Sumber: Purna, 2016.

Kemampuan beradaptasi tersebut di atas sesuai dengan batasan teori fungsional yang mengatakan, bahwa pengalaman beradaptasi terhadap lingkungan hidup manusia secara aktif itu diabstraksikan sebagai perangkat nilai yang kemudian menjadi kerangka acuan yang mendominasi sikap dan pola adaptasi manusia. Bukan hanya peralatan dan teknologi yang dikembangkan manusia dalam beradaptasi terhadap lingkungan hidupnya, melainkan juga sikap dan pola tingkah laku adaptif. Kebudayaan yang semula merupakan himpunan abstraksi pengalaman itu kemudian mendominasi masyarakat pendukungnya. Penilaian manusia terhadap lingkungan dan penataannya, apa yang baik dan buruk, apa yang berharga dan tidak berharga dan apa yang layak dan tidak layak, tidak bebas dari pengaruh kebudayaan yang membesarkan mereka. Demikian pula apa yang baik untuk dimakan, bagaimana mengolah, menyajikan, pengetahuan tentang kandungan yang dibutuhkan manusia, semuanya itu tidak bebas dari dominasi kebudayaan masyarakat yang bersangkutan. Lebih-lebih hubungan alam dan religi. Pengetahuan tentang alam ini seringkali menjadi bagian dari sistem religi, bilamana pengetahuan tersebut 
berhubungan dengan asal mula alam, penciptaan alam, asal mula gejala alam, asal mula gerhana, dan sebagainya. Pengetahuan ini seringkali dianggapnya sebagai mite-mite yaitu cerita rakyat yang dianggap suci, sehingga diyakini menjadi nilai mengatur pola perilaku mereka dalam memanfaatkan alam sekitarnya. Kasus mengaplikasikan teori fungsional ini dapat pula dilihat pada contoh terhadap WBTB Indonesia yang namanya rendang di Sumatra Barat (Ensiklopedi Makanan Tradisional Indonesia, 2004: 252-261).

Pola-pola kegiatan yang terkait dengan pangan itu melembaga sebagai tradisi yang mencerminkan kemampuan masyarakat beradaptasi terhadap lingkungan hidupnya. Sebagai perwujudan adaptasi aktif, makanan tradisional yang dikembangkan itu bukan sekadar untuk memenuhi akan sumber pembangkit energi dalam tubuh manusia, melainkan ia mencerminkan dinamika masyarakat pendukungnya dalam menyikapi kondisi lingkungan hidupnya dalam arti luas. Manusia mengembangkan pangan, bukan semata mengandalkan pada ketersediaan sumber makanan yang tersedia, melainkan juga memperhatikan fungsi religius, fungsi social, fungsi ekonomi, dan fungsi pendidikan. Bahkan dalam menghadapi dunia global dan politik makanan- kuliner dapat dijadikan media diplomasi. Demikian pula mengenai makna yang dimuat dalam makanan tersebut. Apakah mengandung makna religius, sosial, ekonomi dan pendidikan atau makna sosial budaya daripada pangan yang dikembangkan. Karena itu, makanan tradisonal seperti betutu yang amat beragam namanya dan model penyajiannya, serta pengolahannya dapat dicermati dalam wujud, fungsi sosialbudaya dan makna sosial-budaya yang melekat. Karena itu tidaklah mudah untuk mengubah makanan dan pola makan penduduk tanpa memperhatikan kebudayaan yang mendominasinya, seperti perjalanan bumbu-bumbu masakan yang di Bali saat ini sumber dari zaman Majapahit.
Keanekaragaman

makanan tradisonal itu mencerminkan kemampuan adaptasi aktif penduduk dalam upaya memenuhi kebutuhan pangan dengan memanfaatkan sebesar-besarnya sumber daya alam yang tersedia tanpa mengabaikan perangkat nilai dan norma sosial yang berlaku. Keanekaragaman makanan tradisional itu tidak sekadar menjadi kebanggaan yang mencerminkan kekayaan budaya bangsa, melainkan juga sangat penting artinya bagi pelestarian keseimbangan lingkungan (ecologicalequilibrium) serta ketahanan nasional, khususnya di bidang pangan. Tidak banyak orang menyadari akan arti pentingnya makanan tradisional dan berusaha menyisihkannya dengan makanan nasional yang dianggap lebih unggul. Sesungguhnya berbagai jenis makanan tradisional, baik sebagai makanan pokok maupun penganan, baik makanan seharihari maupun perjamuan sosial, ekonomi serta religius itu dikembangkan memenuhi fungsi sosial serta makna simbolik (budaya).

\section{B. METODE PENELITIAN}

Metode penelitian ini menggunakan metode kualitatif yang bertumpu pada paradigma deskriptif interpretatif dan paradigma teori sosial kritis (Ritzer, 2012). Data primer yang diperoleh di lokasi penelitian di Desa Peliatan, Gianyar, Bali diperoleh melalui daftar pertanyaan yang berstruktur sesuai dengan jenis fungsi dan makna yang ingin diperoleh. Dalam penelitian ini teknik sampling yang digunakan adalah purposive sampling dan snowball sampling. Purposive sampling adalag pengambilan sampel diambil berdasarkan kebutuhan penelitian, sedangkan snowball sampling adalah teknik pengambilan sampel sumber data yangpada awalnya jumlahnya sedikit tersebut belum mampu memberikan data yanglengkap, maka harus mencari orang lain yang dapat digunakan sebagai sumber data (Sugiyono, 2008: 300). Sehingga daftar pertanyaan ditujukan kepada informan yang memiliki pengetahuan 
tentang betutu dan pengetahuan tentang kebudayaan Bali serta agama Hindu. Pengungkapan tentang fungsi dan makna ini tidak saja secara emik lewat wawancara mendalam terhadap 10 orang informan seperti tukang banten, juru masak, pemangku, sulinggih, agamawan, dan lainlain tetapi disertai pula dengan observasi terhadap beberapa industri rumah tangga yang menjual betutu maupun rumah makan. Selain itu, dilakukan studi dokumentasi terutama hasil penelitian kuliner yang ada di perpustakaan Balai Pelestarian Nilai Budaya Bali.

\section{HASIL DAN BAHASAN}

Lokasi penelitian merupakan sebuah desa yang terletak di Kecamatan Ubud, Kabupaten Gianyar Propinsi Bali. Desa ini memiliki wilayah seluas 4, $93 \mathrm{~km}$ persegi. Desa ini berbatasan langsung dengan Desa Ubud sehingga pengaruh Ubud sangat besar terhadap desa ini, dan juga menjadi salah satu potensi wisata di wilayah Kabupaten Gianyar. Selain relatif subur letak Desa Peliatan yang berada di wilayah perbukitan, menyebabkan suasana udara yang relatif sejuk, sehingga wisatawan relatif banyak dan betah tinggal di daerah ini. Di desa inilah banyak sekali bermunculan kuliner khas Bali termasuk salah satunya adalah Betutu yang selalu dikonsumsi sehari-hari maupun pada acara acara tertentu.

Betutu sebagai fungsi Diplomasi kedalam antara lain :

\section{Fungsi Religius}

Kehidupan religius pada dasarnya merupakan kepercayaan atau keyakinan terhadap adanya gejala-gejala alam, kekuatan gaib luar biasa atau supernatural yang berpengaruh terhadap kehidupan individu dan masyarakat. Kepercayaan itu menimbulkan perilaku tertentu seperti berdoa, memuja dan lainnya, serta menimbulkan sikap mental tertentu seperti rasa takut, rasa optimis, pastrah dan yang lainnya dari individu dan masyarakat yang mempercayainya. Karenanya petunjuk dan ketentuan kekuatan gaib harus dipatuhi kalau manusia dan masyarakat ingin kehidupannya berjalan dengan baik dan selamat (Bustanudin, 2006: 1). Makanan tradisional/khas Bali yang secara harafiah sudah berkembang sejak masuknya agama Hindu di Bali, telah menjadi makanan asli Bali, bukan saja untuk masyarakatnya, tetapi juga secara religius diperuntukkan bagi para Dewa-Dewi sesuai kepercayaan mereka. Makanan khas semacam ini digolongkan dalam lontar "Indik Maligia", yang sangat berbeda dengan makanan yang diperuntukkan bagi manusia Bali, yang dikelompokkan dalam lontar "Dharma Caruban” (Marsiti, 2017: 517.)

Dalam sistem religi pada berbagai etnis sering dijumpai kenyataan bahwa sajian makanan tertentu digunakan sebagai "persembahan" dari alam manusia kepada alam kedewataan/ke tuhanan. Itu tergolong sebagai apa yang disebut "sajen", yang akan dihirup sarinya oleh penguasa alam gaib yang dituju. "Sajen" itu dapat berupa makanan olahan seperti betutu, dari bahan mentah misalnya buah-buahan, yang bisa disertai pulabenda-benda khusus seperti kemenyan, dupa, canang, tirta, dan lainlain. Sudah tentu setelah upacara selesai komponen boga dalam sesajen itu boleh dimakan oleh khalayak.

Hal tersebut di atas sejalan dengan satu diantara tiga kerangka agama Hindu dan wajib harus dijalankan bagi seluruh umat Hindu yang ada di Bali, yaitu menyelenggarakan sarana upakara (yadnya). Sarana sebenarnya merupakan alat untuk membantu mempercepat konsentrasi pikiran manusia dalam mendekatkan dirinya dengan Tuhan. Pada umumnya umat Hindu yang menganut aliran Siwa-Sidanta dalam persembahyangan paling dominan mempergunakan cara arcana, yaitu mempersembahkan sajen (banten) yang penuh simbolisme. Selanjutnya seluruh upacara diserahkan sepenuhnya kepada para Pinandita (sebutan lumrah Pemangku), atau kelompok Sulinggih, seperti, Ida Pedanda, Rsi, Sri Empu, Dukuh, Sri Begawan dan sebutan lain 
sesuai dengan konsep Sarwa Sadaka, bukan sebatas Tri Sedaka (Ida Pedanda Siwa, Ida Pedanda Buda dan Ida Bujangga Wesnawa) saja yang diperkenankan untuk "muput", mendoakan (ngastawang) sesajen.

Umat hanya berpartisipasi pada waktu menghaturkan sembah bakti, dengan cakupan tangan. Sementara itu, mantra dan doa diucapkan oleh pandita dan pinandita. Dalam penyelenggaraan upacara ada beberapa upacara yang harus dilengkapi sesajennya dengan betutu, baik betutu bebek maupun betutu ayam, seperti pada saat penyelenggaraan otonan (tergolong upacara manusa yadnya), banyu pinaruh, tumpek uduh, tumpek landep, upacara ngasti dan jika ada yang berkaul (mesaudan), pada sesajen genah bawa, pada sesajen prananya. Jenis betutu yang dipersembahkan betutu bebek.

Memposisikan maupun pemilihan betutu bebek dalam perlengkapan upacara agama tersebut di atas dapat dumaklumi. Karena binatang bebek sebagai simbol binatang yang disucikan. Binatang suci yang dimaknai sebagai binatang yang mampu membedakan antara yang baik dan buruk, antara yang berharga dan tidak berharga, antara yang layak dengan tidak layak, dan pantas dan tidak pantas. Dalam kenyataan sehari-hari pada saat makan, binatang bebek tidak pernah saling berebut makanan. Apalagi saling patuk. Binatang bebek bisa memilih dan memilah mana makanan yang pantas dimakan, sehingga binatang bebek sering juga dimaknai sebagai binatang simbol kebijakan. Hidangan makanan orang suci (brahmana) pada saat penyelenggaraan upacara agama umumnya betutu bebek. Bukan betutu ayam.

Dalam sastra agama mengingatkan didalam upacara caru atau tawur bahwa sang kala bersemayam di bhuana alit (sarira) setiap orang dalam artian karakteristik yang selalu menggoda pikiran setiap orang. Karenanya pikiran itu ibarat air di daun talas. Artinya tidak tetap pendirian. Untuk mengantisipasi keadaan itulah, maka umat Hindu di Bali tidak henti-hentinya beryadnya, selalu ingat dengan amanat sastra agama Hindu, agar bisa hidup tentram dan damai. Terbukti dalam kehidupan sehari-hari umat Hindu di Bali setiap hari Kliwon mempersembahkan kepada Bhuta Kala, dalam bentuk yang paling sederhana berupa segehan panca warna, yakni: putih, merah, kuning, hitam kemudian brumbun (lima warna) yang diletakkan di lebuh (pintu masuk pekarangan rumah).

Fungsi binatang ayam maupun bebek diawali dari caru maupun tawur. Karena itu dari semua jenis binatang ayam maupun bebek menjadi amat penting, seperti: (1) pada Caru Eka Sata menggunakan sarana ayam panca warna atau brumbun dan cukup hanya satu ekor ayam, disertai banten panca sanak, disebut Caru Pangruwak. Satu ekor ayam warna putih tulus namanya Caru Dengen, satu ekor ayam warna merah namanya Caru Preta, satu ekor ayam warna putih, paruh kuning dan kakainya kuning (putih siungan) namanya Ananta Suksma, satu ekor ayam warna hitam namanya Caru Becaruk. (2) Caru Panca Sata, dengan menggunakan sarana lima ekor ayam, warna putih tulus, warna merah, warna putih suing, hitam dan brumbun yang beradaptasi dengan arah timur, selatan, barat, utara dan di tengah, disertai banten panca sanak dalam wujud jejahitan dari daun janur tua (slepan). Menggunakan lima ekor ayamsebagai wujud Panca Maha Bhuta dan dipersembahkan kepada Panca Durga Dewi, amanca desa tempatnya sesuai arah, timur, selatan, barat, utara, dan ditengah serta warnanya putih, merah, kuning, hitam, dan brumbun. (3) Caru Panca Mabaya, kalau bebek welang kalungsebagai tambahan lima ekor ayam itu rerentannya sama dengan caru asu, yang dipersembahkan kepada panca maha bhuta-bhuti. (4) Caru Panca Durga, memakai lima ekor ayam disertai bebek berbulu sikep saja dan dasarnya caru semuanya, sorohan bebangkit. (5) Caru Panca Kelud, dasarnya Caru Panca Sata 
ditambah dengan bebek berbulu sikep (bulu elang), dan asu bang bungkem. (6) Caru Rsi Gana, memakai lima ekor ayam ditambah dengan bebek berbulu warna putih dan ditambah asu bang bungkem, gelar sanga yang diperagakan dalam bentuk sesajen nasi dengan sembilan warna. (7) Caru Panca Sanak, sebagaimana upakaranya Panca Kelud, kalau ditambah kambing, angsa, dan bebek welang kalung sebagai inti pokok caru tersebut. (8) Caru Balik Sumpah, sebagaimana tersebut di atas dan ditambah dengan seekor babi butuhan. (9) Caru Tawur Gentuh, bila ditambah dengan seeokr sapi, yang menjadi utamaning wong sudra. Bagi wong menakcaru ini tergolong madya. (10) Tawur Agung, sebagaimana di atas ditambah dengan seekor kerbau, pasapuh-sapuh kamenaniya, nistaning sang ratu caru itu. (11) Pambaligya Bhumi Masapuh, Caru Panca Sanak ditambah dengan tiga ekor kerbau, sebagai madyaning bhumi caru. (12) Panca Bali Krama, bila menggunakan lima ekor kerbau sebagai inti pokok. Namun tetap didasari Caru Panca Sanak. (13) Tawur Eka Dasa Ludra, dengan menggunakan dua puluh enam ekor kerbau sebagai inti pokok caru, namun tetap didasari dengan Caru Panca Sanak. (14) Pambaligya Resu Bhumi, dengan memakai empat puluh ekor kerbau sebagai utamaning utama pangaciaciangumi, namun tetap didasari dengan Caru Panca Sanak.

\section{Fungsi Sosial}

Makanan merupakan media penting dalam upaya manusia berhubungan satu sama lain. Di dalam rumah tanggakehangatan hubungan antar anggotanya terjadi pada waktumakan bersama. Begitupun di antara rumah tangga diupayakan pertemuan secara berkala dengan makan untukmemelihara dan mempererat hubungan silaturahmi. Antara tetangga, sering dilakukan tukar menukar makanan (Mapandin, 2006: 20).

Sehingga pasti dipahami bahwa suatu makanan memiliki banyak arti. Makanan tidak hanya untuk mengenyangkan perut tetapi untuk membentuk hubungan antara orang- orang dengan lingkungan sekitarnya serta dengan kepercayaan mereka. Maka dari itu, makanan merupakan hal yang penting untuk kehidupan sosial. Bagi masyarakat Bali, makanan yaitu betutu kerap kali dan sangat lazim digunakan untuk menjalin hubungan kekerabatan, pertemanan dan persaudaraan. Hampir pada setiap kegiatan hajatan, menu betutu selalu disuguhkan untuk tamu undangan, para saudara atau teman-teman yang telah membantu dan bergotong royong menyiapkan kegiatan upacara atau hajatan tersebut, dan menyantap hidangan betutu dengan makan bersama.

Pada saat penyelenggaraan upacara agama baik upacara dewa yadnya, pitra yadnya, manusa yadnya, bhuta yadnya, dan rsi yadnya selalu ada acara makan bersama atau resepsi atau jot-jotan kepada anggota masyarakat krama desa maupun banjar. Kehadiran orang pada saat penyelenggaraan upacara agama dimaksudkan sebagai doa dan salah satu dari tiga saksi (tri upa saksi) dalam upacara. Ketiga saksi itu yaitu dewa saksi, manusa saksi dan bhuta saksi. Menghadirkan manusia dalam upacara pada umumnya pasti dijamu dengan makanan. Salah satu pelengkap menu makanan yaitu betutu. Betutu ayam dianggap paling tepat untuk melengkapi hidangan, karena dianggap paling netral untuk mewujudkan kerukunan, persaudaraan antarbeda agama, dan etnis. (Jika mengundang dari berbagai pemeluk agama yang diundang). Jika ada tetangga yang menyelenggarakan upacara, tidak sedikit dari tetangganya ngejot (mengantarkan) betutu kepada yang menyelenggarakan upacara sebagai wujud hubungan ketetanggaan yang baik, atau wujud kerukunan dengan tetangga. Bahkan dalam hubungan antarmanusia untuk penggalian dana, betutu juga dipergunakan untuk bukti undangan dalam saat penyelenggaraan tajen (sabung ayam). 
Binatang bebek dan ayam bagi masyarakat (etnis) Bali mempunyai kedudukan penting dalam setiap upacara.Kedudukan penting yang dimaksud diawali dari penggunaan bebek dan ayam dalam upacara caru atau tawur. Caru atau tawur yang tujuannya memelihara keseimbangan (ekuilibrium) alam semesta agar senantiasa lestari. Dengan memberi jotanbetutu hubungan tetangga juga memiliki makna kerukunan persaudaraan.

Jika diamati lebih jauh, bahwa kata caru dalam bahasa Bali mirip dengan katakata "carem" dan "carob", yang mengandung arti tunggal, yang intinya persatuan dan kesatuan mulai dari tingkat keluarga inti, sampai ke tingkat yang lebih luas, yaitu masyarakat. Karena itu tidak mengherankan kalau bahan betutu dari binatang bebek dan ayam selalu dijadikan menu untuk jamuan makan yang dihidangkan kepada para tamu yang dalam upacara, baik dalam upacara Dewa Yadnya, Pitra Yadnya, Manusa Yadnya, Bhuta Yadnya, dan Rsi Yadnya. Kedua jenis binatang ini tidak susah memeliharanya. Untuk berkembang biak sangat mudah. Jika kedua jenis binatang ini sudah banyak, maka perlu dibuat kebijakan untuk keseimbangan dengan mengolah dalam bentuk makanan. Apakah makanan akan dipersembahkan untuk kegiatan yadnya (upacara), sosial, makanan sehari-hari yang bisa dinikmati oleh semua anggota keluarga maupun untuk kebutuhan ekonomi yang diperjualbelikan.

Betutu sebagai fungsi diplomasi keluar dapat dilihat dari :

\section{a. Fungsi Ekonomi dan Pariwisata}

Seni kuliner Bali termasuk di dalamnya adalah olahan betutu, merupakan salah satu daya tarik wisata Bali diharapkan mampu bersaing dengan kuliner asing. Makanan khas Bali ini dapat dipromosikan sebagai hidangan, diharapkan nantinya dapat dinikmati tidak hanya oleh tamu lokal tetapi juga tamu asing. Oleh karena itu Bali diharapkan dapat mengembangkan wisata boga, dimana makanan khas Bali digunakan sebagai objek dan aset pariwisata yang mampu menggugah minat wisatawan untuk menikmati masakan tradisional Bali (Suardani, 2013:151).

Sehingga dalam perkembangan betutu tidak saja difungsikan sebagai pelengkap upacara Panca Yadnya, hidangan kepada para tamu yang hadir pada saat penyelelengaraan upacara keagamaan, dan adat. Namun semenjak kehadiran pariwisata di Bali betutu semakin dikenal. Betutu sudah mulai dijual untuk konsumsi masyarakat umum. Betutu lebih dikenal dan diminati dibandingkan be guling dari bahan babi oleh para tamu. Hal ini dapat dimaklumi, karena faktor pantangan terhadap makanan tertentu, halal dan tidak halal, haram dan tidak haram bagi agama tertentu. Saat ini di Kota Denpasar maupun kotalainnya di Bali, banyak ditemukan warung makan yang menjual betutu. Bahkan tidak sedikit yang menjual betutu di rumah-rumah penduduk tanpa promosi memakai papan nama atau label pengenal lainnya. Dikenal oleh masyarakat karena promosi dari mulut ke mulut.Terutama yang dijual betutu ayam baik ayam kampung maupun ayam petelor (ayam merah) dan ayam potong (boiler).

Usaha betutu memiliki potensi untuk mendatangkan keuntungan dan peluang ekonomi yang sangat menggiurkan. Peluang dalam usaha betutu juga sangat bagus dan masih terbuka lebar bagi siapa saja yang ingin menerjuni usaha tersebut. Peminat ayam betutu kini semakin besar sehingga potensi usaha ayam betutu semakin sangat potensial. Usaha ayam betutu merupakan salah satu usaha kuliner berbahan ayam menguntungkan yang dapat dipilih sebagai usaha yang menjanjikan keuntungan bagi para pelakunya. Banyak orang yang menggemari olahan ayam betutu, sehingga kedatangan betutu ini kini banyak dicari. Pangsa pasar olahan betutu menjadikan peluang untuk usaha ayam betutu kini semakin berpotensi lebih 
menjanjikan. Meski usaha ayam bakar betutu ini mulai banyak bermunculan di masyarakat namun penggemar ayam bakar betutu kini tak pula surut bahkan terus bertambah. Tingginya penggemar ayam betutu, membuat usaha ayam betutu ini berkembang pesat hingga sekarang.Usaha ayam betutu kini menjadi salah satu tren bisnis yang menguntungkan. Banyak orang yang tertarik untuk menggeluti usaha ayam betutu. Usaha ayam betutu terbilang laku keras di pasaran sehingga hal wajar jika usaha betutu kini tengah diincar dan diburu masyarakat. Usaha ayam betutu menjadi salah satu usaha kuliner masakan yang menjanjikan dengan laba yang patut untuk diperhitungkan. Kondisi ini membuka peluang untuk pemerataan, dan peningkatan perekonomian masyarakat, bukan sebatas identitas budaya (Pembangunan Kebudayaan tahun 2013 2025). Masyarakat memperoleh keuntungan secara ekonomi dari hasil penjualan masakan betutu.

Tidak sedikit para penjual ayam kampung, ayam petelor (merah) dan ayam potong ikut mendapat keuntungan karena memasok bahan baku ayam betutu. Secara langsung mendapat keuntungan finansial dan omset penjualan ayam sebagai bahan betutu semakin meningkat. Demikian pula yang mempunyai keahlian memasak betutu, dan para pramusaji, tukang parkir yang berada di sekitar warung akan ikut menikmati dampak kuliner betutu. Ada pula profesi sebagai pengepul ayam, tukang potong ayam, tukang membersihkan ayam, petani, dan lain-lain. Mereka mendapat upah dari kegiatan yang dilakukan.

Masyarakat yang memperoleh peningkatan ekonomi dari kuliner betutu, bukan semata-mata masyarakat di pusat pembuatan dan penjualan betutu, namun juga masyarakat lain, seperti juru jual sekam sebagai alat pembakar, atau penjual kayu api bagi penjual betutu yang menggunakan kayu api maupun arang kayu, pencari kelopak daun pohon pinang sebagai alat pembukus pembakaran, pemasok, peternak ayam tidak saja yang ada di Bali, juga luar Bali. Karena ayam dan bebek yang ada di Bali juga dipasok dari luar Bali seperti dari Jawa.

Dunia pariwisata mempunyai kaitan erat dengan kuliner. Dunia pariwisata dan kuliner sangat berkaitan dengan lapangan kerja. Pariwisata, kuliner dan tenaga kerja sangat berkaitan dengan peningkatan ekonomi. Untuk membangkitkan pariwisata, kuliner dan tenaga kerja, tentu masyarakat harus mampu memanfaatkan kearifan lokal (local genius). Betutu merupakan salah satu kearifan lokal yang sudah teruji keberadaannya sampai sekarang. Jenis kuliner yang terbuat dari ayam maupun bebek, yang sementara ini tidak hanya ada di Bali. Tidak bisa dipungkiri lagi bahwa betutu sudah dikenal dan menjadi makanan khas Nusantara. Oleh karena itu, tidak mengerankan apabila setiap tamu yang datang ke Bali pasti mencari dan menikmati makanan betutu. Bahkan tidak sedikit memesan betutu dijadikan oleh-oleh. Banyak warung, rumah makan, restoran berkelas, restoran yang berada di hotel-hotel yang menyajikan makanan khas Bali ini. Menurut informasi di tempat pembuatan betutu Bapak Presiden Suharto beberapa kali memesan betutu ala Pliatan ini. Pada saat turis banyak datang ke Bali, betutu Pliatan ini sampai menghabiskan 75 ekor per hari.

Dewasa ini masakan khas Bali betutu ini sudah merambah beberapa kota di Indonesia, seperti kota Mataram, Jakarta, Surabaya, dan lain-lain. Karena rasanya yang unik, baunya harum, dan lezat dan unsur kenetralannya terhadap semua agama dan etnik menjadikan masakan ini sebagai peluang bisnis untuk mendirikan rumah makan dengan menjual menu betutu di beberapa kota di Indonesia. Untuk daya tarik selera betutu juga dilengkapi dengan kehadiran sambal matah. Sambal yang serupa-bening, tidak berwarna, rasanya cenderung pedas asam dan menyegarkan, sementara dapat ditemukan di Bali, Flores, Sumba, sampai 
ke Manado.Sambal sejenis ini nyaris tidak dikenal di Jawa. Tentu ini menandakan pergeseran selera makan dari merah, panas, pedas ke bening, asam, pedas. Sambalnya lebih "menyegarkan" daripada memeras keringat, dan pedasnya lebih tajam. Sementara di Jawa pedasnya lebih ke "panas". Namun patut diketahui, menikmati masakan betutu yang berlokasi di Bali jauh lebih nikmat, indah, puas jika dibandingkan menikmatinya masakan betutu yang berada di luar Bali. Hal ini disebabkan taksu, yaitu suatu kekuatan spiritual yang sifatnya niskala (tidak nyata, tidak material). Kehadiran taksu sangat tergantung dari kemurahan Hyang Widhi Wasa dan roh-roh suci lainnya dan keadaannya membawa dampak luar biasa terhadap kualitas aktivitas sosial dan budaya manusia (Dibia, Wayan, 2012). Walaupun bahan ayam, bebek, bumbu, dan teknis pembuatanya sama. Contoh taksu yang dapat dibuktikan di sejumlah tempat di Kabupaten Gianyar yang berkaitan dengan dagang makanan tradisional yaitu dagang nasi babi guling di kota Gianyar, dan dagang nasi ayam Warung Jero Mangku Kedewatan, Warung Teges di Peliatan.

Perkembangan kuliner betutu akhirakhir ini selalu meningkat, terbukti jumlah warung, rumah makan, restoran dengan berbagai merek atau bermaca-macam nama betutu. Perkembangan sejalan dengan kehadiran wisatawan yang datang ke Bali. Para wisatawan ingin menikmati betutu terutama betutu yang ada di Pliatan dapat dimaklumi. Pasalnya, betutu yang beralamat di Pliatan tidak memakai penyedap. Rasa lezat hanya mengandalkan dari bumbu lengkap (jangkep). Untuk meyakinkan minat dan selera masyarakat, dari aspek kesehatan betutu telah diteliti oleh tim Pusat Penelitian Makanan Tradisional (PPMT) Lembaga Penelitian dan Pengabdian Kepada Masyarakat (LPPM) Universitas Udayana, bahwa cara memproduksi mulai dari pembersihan betutu sudah menggunakan air bersih baik yang berasal dari PDAM, air dari gunung dan air sumur. Aspek sanitasi bahan-bahan dan peralatan yang digunakan dalam proses pengolahan umumnya cukup bagus, kandungan coliform 0,28 x 10, kadar air, abu protein, kadar lemak, dan karbohidrat masing-masing 60,87;1,84;14,69; 1,27; 21,33( Yusa, Ni Made, dkk., 2014).

Dalam perkembangan selanjutnya makanan tidak hanya memiliki fungsi kebutuhan maupun kelangsungan hidup, sebagai wujud rasa syukur untuk melengkapi upacara, penghormatan kepada raja (penguasa), penghormatan antarbeda agama dan etnis, kepentingan ekonomi dan pariwisata. Sampai ada penyebutan wisata kuliner. Wisata kuliner yang selalu dikaitkan dengan hasil pengolahan dan proses memasak, hasil masakan, dan makanan khas yang menjadi salah satu identitas daerah. Namun yang tidak kalah pentingnya dewasa sekarang, yaitu apakah makanan yang dimakan sudah mengandung unsur sehat dan tidak sehat yang berkaitan dengan gizi dan kembali ke alam (back to nature), sehingga tidak mengherankan, jika betutu akan semakin popular seiring dengan perkembangan pariwisata. Fungsi di bidang ekonomi semakin meningkat. Lebih-lebih orang Bali sendiri dan kehadiran para wisatawan menginginkan dengan gaya hidup yang kembali ke alam (back to nature) dan sikap glokalisasi (menghargai kebudayaan lokal dan mengkemas produksi lokal dalam sentuhan global). Gaya hidup modern dan kehidupan masyarakat global dianggap telah mencapai titik jenuh sehingga pemikiran kembali ke alam dan mencintai produk dan budaya lokal semakin meningkat dalam pandangan hidup masyarakat (Sudarma, dkk., 2014: 7-11).

Dalam fenomena seperti tidak menutup kemungkinan dalam diversifikasi usaha kuliner akan meningkat. Orang luar Bali akan tertarik untuk mempelajari skil pembuatan, dan mengkomersialkanbetutu tersebut, sekaligus akan mengajarkan kecintaan terhadap alam sekitar. Terutama yang berkaitan dengan bahan-bahan yang dipergunkan bersumber dari alam. Oleh 
karena betutu ini bisa dipelajari proses pembuatannya dan bisa dikomersialkan. Bahkan dijadikan media diplomasi antara etnik, bangsa dan antarpemeluk agama yang ada di dunia.

\section{b. Betutu Bali sebagai Kuliner Diplomasi}

Konsep diplomasi kuliner atau gastro diplomacy dapat digunakan oleh negara untuk menciptakan pengertian lintas budaya dengan harapan dapat meningkatkan interaksi dengan publik atau masyarakat yang menjadi target. (Jiun, 2018: 3)

Peluang diplomasi budaya Indonesia melalui media kuliner (makanan) adalah sangat besar. Meskipun terkesan sederhana, ternyata makanan pun bisa menjadi salah satu altematif penunjang dalam implementasi pengenalan soft diplomacy Indonesia. Bahkan kenyataannya makanan merupakan media yang paling efektif untuk membangun hubungan kedekatan secara emosional. (Gabriella, 2013:91).

Diplomasi ini memanfaatkan makanan dan masakan untuk menciptakan pemahaman lintas budaya dengan harapan bisa meningkatkan interaksi antara kedua pihak. Indonesia yang dianugerahi beragam kuliner tentu saja dengan mudah melakukan gastrodiplomacy ini (https://tirto.id/kekuatan-diplomasi-

kuliner-bwhl).

Megibung pada masyarakat Bali telah dikenal, dan merupakan budaya makan bersama sejak zaman dulu. Hal tersebut menunjukkan bahwa makan bersama dapat menjadi wadah silaturahmi hingga penyelesaian masalah. Lewat makanan, para pemimpin dapat menggunakan kekuatan tersebut untuk berdiplomasi lewat sajian dan makan bersama. Dari diplomasi makan bersama, perasaan berjarak yang biasanya dimiliki pemimpin langsung cair dengan sendirinya.

Merujuk dari dasar pemikiran yang dikemukakan oleh Morgenthau (dalam
Indra Keteran), bahwa kekuatan dan prestise suatu negara maupun bangsa yang diperjuangkan oleh para elit politiknya dapat dilihat pada kejelian menggunakan potensi negaranya. Satu diantara potensi negara yaitu dari lensa makanan betutu. Karena sementara ini yang dipakai rujukan saat berdiplomasi hanya seni-budaya Bali saja.Penulis yakin, bahwa kekuatan dari makanan-kuliner betutu bisa mengubah perilaku aktor/elite politik. Karena makanan ini juga merupakan simbolisme dan budaya Bali. Makanan ini juga dapat dijadikan instrumen senjata kewibawaan baik pada saat melobi maupun saat negosiasi. Melalui makanan ini juga dapat memperlihatkan sifat keramahtamahan, wibawa, kekuatan dan kelembutan, sejarah, keragaman potensi etnis dan agama (kebhinneka-tunggalikaan Indonesia dalam masakan) Indonesia. Karena betutu merupakan kuliner halal, bergizi, sehat, dan telah memiliki sejarah panjang. Oleh karena itu tidak mengherankan betutu dapat diberi nama kulineryang "beradab" yang dimiliki bangsa Indonesia umumnya dan etnis Bali khususnya. Masyarakat Balitelah memberi apresiasi terhadap betutuyaitu sebagai kuliner yang mampu memenuhi kebutuhan hidup rukun dan toleran dalam dunia sekala (dunia nyata) sampai niskala (dunia gaib), atau dari dunia profan sampai dunia sakral. Untuk memperkuat pernyataan tersebut di atas, status dan kedudukan betutu Bali sudah mendapatkan penetapan sebagai Warisan Budaya Takbenda (WBTB) Indonesia dari Kemendikbud, sehingga karya budaya ini bukan milik etnis Bali saja, tetapi juga menjadi milik bangsa Indonesia. 


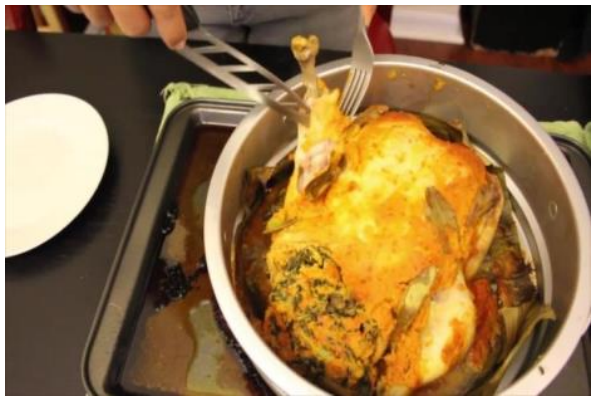

Gambar 3. Betutu Siap Disantap Sumber: Purna, 2016.

\section{PENUTUP}

Dari uraian pembahasan karya budaya Betutu Bali: Kuliner Diplomasi Budaya Indonesia dapat disimpulkan dan disarankan bahwa:

1) Keberadaan kuliner betutu Bali, sudah mengalami perjalanan sejarah yang sangat panjang,baik teknik proses pengolahannya maupun fungsinya. Keberadaan dewasa sekarang sudah mengalami perkembangan pengayaan sesuai dengan kondisi zaman.

2) Pada awalnya betutu difungsikan sebagai diplomasi kedalam, yakni sebagai sarana persembahan terhadap Ida Hyang Widhi Wasa melalui upacara Dewa Yadnya. Namun selanjutnya dipersembahkan juga untuk kelengkapan Yadnya yang lain seperti Pitra Yadnya, Buta Yadnya, Rsi Yadnya, dan Manusa Yadnya, sehinggatidak mngherankan betutu memiliki fungsi religius,dan sosial.

3) Karena etnis Bali yang beragama Hindu selalu aktif dalam menghadapi lingkungan sosial, budaya, alam yang ditempati dan dunia global, maka betutu tidak saja dijadikan menu makanan para raja, dan kaum elite, namun juga sebagai menu tradisional yang disantap sehari-hari oleh orang kebanyakan. Bahkan dewasa sekarang dikomersialkan sebagai konsumsi wisatawan domestik maupun manca negara. Cara pandang terhadap betutu bukan sekadar makanan untuk memenuhi selera dan mengisi perut lapar, namun sudah mengarah ke pengertian kuliner yakni, seni persiapan, hasil olahan dan presentasi penyajian masakan yang dilakukan oleh juru masak etnis Bali sendiri. Kuliner betutu pun mengalami berbagai nama, betutu Pliatan, betutu Men Tempeh, betutu Gilimanuk, betutu Liku, betutuayam Kedewatan, dan lain-lain.

4) Dalam rangka menghadapi dunia politik global, betutu pun sudah berhubungan dengan pemahaman konsep "diplomasi", yakni suatu strategi, taktik dan siasat untuk melakukan pengorganisasian lobi dan negosiasi dalam menyelesaikan perbedaan dalam perundingan. Betutu sudah disajikan di hotel-hotel berbintang dan rumah makan bertaraf international. Betutu dapat digolongkan sebagai jenis kuliner yang halal (bukan haram), mampu menjembatani lintas budaya dan toleran terhadap semua kelompok agama, maupun etnis dan bangsa.

5) Betutu Bali mampu membangun kekuatan prestise para diplomatik dan pemerintah Indonesia.

Atas kondisi tersebut alangkah baiknya apabila:

1) Pemerintah Kabupaten/Kota dan Propvinsi serta masyarakat budaya segera mencatat Karya Budaya Takbenda yang dimiliki. Selanjutnya mengusulkan Karya Budaya Takbenda (intangible) umumnya dan jenis kuliner khususnya melalui Dinas Kebudayaan Provinsi ke Direktorat Warisan dan Diplomasi Budaya, Direktorat Jenderal Kebudayaan, Kemendikbud.

2) Oleh karena, beberapa jenis karya budaya kuliner yang dimiliki etnis di Indonesia sudah mendapat pengakuan dan penetapan sebagai Warisan Budaya Takbenda Indonesia seperti, rendang (Sumatra Barat), se' $i$ (Nusa Tenggara Timur), ayam Taliwang (Nusa Tenggara Barat), 
dan karya budaya betutu Bali (dalam proses pembahasan untuk mendapatkan pengakuan dan penetapan), lain-lain, maka sebaiknya pemerintah daerah dan pusat meluncurkan Program "Prakarsa Diplomasi Kemitraan Makanan Warisan Tradisonal (Diplomecy Initiative Partnership Heritage Traditional Food), sehingga jenis kuliner yang sudah mendapat pengakuan dan penetapan serta yang akan diusulkan akan cepat popular.

3) Dengan adanya program seperti tersebut di atas dampaknya tidak saja memperlihatkan langkah pelestarian kekayaan keragaman kuliner suku bangsa (etnis), juga akan memperkuat program meragamkan (diversifikasi) makanan dan menu wisatawan, namun juga ikut menyelesaikan masalah isu-isu bilateral, multilateral dan lokal di meja makan dengan mitra kerja Pemerintah Indonesia baik itu diselenggarakan di dalam negeri maupun di berbagai acara internasional maupun di berbagai perwakilan Indonesia di luar negeri.

\section{DAFTAR SUMBER}

\section{Jurnal, Makalah, Skripsi dan Tesis}

Gabriella, Clarisa. 2013.

Peran Diplomasi Kebudayaan Indonesia Dalam Pencapaian Kepentingan Nasionalnya.Skripsi. Makassar: Jurusan Ilmu Hubungan Internasional Fakultas Ilmu Sosial Dan Ilmu Politik Universitas Hasanuddin.

Jiun, Sarah Minotti. "Diplomasi Kebudayaan Indonesia Terhadap Amerika Serikat Melalui Kuliner (Gastrodiplomacy) tahun 2010-2016" dalam JOM FISIP Vol. 5 Edisi I. Januari - Juni 2018.

Mapandin, Wahida Y. 2006.

Hubungan Faktor-Faktor Sosial Budaya Dengan Konsumsi Makanan Pokok Rumah Tangga Pada Masyarakat Di Kecamatan Wamena, Kabupaten Jayawijaya Tahun 2005. Tesis.
Semarang: Program Pascasarjana Universitas Diponegoro.

Marsiti, Cokorda Istri Raka; Ni Made Suriani; $\mathrm{Ni}$ Wayan Sukerti. "Strategi Pengembangan Makanan Tradisional Berbasis Teknologi Informasi Sebagai Upaya Pelestarian Seni Kuliner Bali”, Makalah dalam Seminar Nasional Riset Inovatif, 2017.

Suardani, Made. "Analisis Keputusan Pengunjung Membeli Ayam Betutu Pada Rumah Makan Ayam Betutu Khas Gilimanuk di Tuban Bali" dalam SOSHUM JURNAL Sosial dan Humaniora, Vol. 3, No. 2, Juli 2013.

Yudha, I Putu Putra Kesuma. "Sate dan Stratifikasi Sosial Masyarakat Desa Adat Blayu" pada Jurnal Penelitian Sejarah dan Nilai Tradisional BPNB Bali Vol 22 No 2. 2015.

\section{Buku}

Bustanudin, Agus. 2006. Agama Dalam Kehidupan Manusia, Pengantar Antropologi Agama. Jakarta: PT Raja Grafindo Persada.

Dibia, I Wayan. 2012.

Taksu dalam Seni dan Kehidupan Bali. Denpasar:Balimangsi.

Kementrian Pendidikan Kebudayaan. 2004. Ensiklopedia Makanan Tradisional Indonesia(Sumatra).Jakarta:Proyek Pengembangan Tradisi dan Kepercayaan Ditjenbud.

Melalatoa, Yunus. 1995.

Ensiklopedi Suku Bangsa di Indonesia. Jakarta: Depdikbud.

Ritzer. 2012

Teori Sosiologi: dari Sosiologi Klasik sampai Perkembangan Terakhir Postmodern. Terjemahan Sahut Pasaribu. Jakarta: Pustaka Pelajar.

Sedyawati, Edi. 2014.

Kebudayaan di Nusantara dari Keris, Tortor sampai Industri Budaya. Jakarta: Komunitas Bambu.

Suarsana, I Made; I Made Purna; I Made Dharma Suteja; I Wayan Suca Sumadi; Raj. Riana Dyah P. 2016. Inventarisasi dan Perlindungan Karya Budaya Betutu 
di Banjar Teruna, Desa Peliatan

Kecamatan Ubud, Gianyar, Bali.

Penerbit Kepel Press.

Sudarma, Wayan, I Gusti Ayu Armini, I Gusti

Ayu Agung Sumarheni. 2014.

Inventarisasi Perlindungan Karya

Budaya Kuliner Taliwang. Denpasar:

BPNB Bali, NTB, NTT.

Sugiyono, 2008.

Metode Penelitian Kuantitatif Kualitatif dan $R \& D$. Bandung: Alfabeta

Sulasman, H. dan Setia Gumilar. 2013. Teoriteori Kebudayaan. Bandung: CV. Pustaka Setia.

Sunjata, Wahyudi Pontjo. 2014.

Kuliner Jawa dalam Serat Centhini. Yogyakarta:BPNB DIY, Jateng dan Jatim.

Yusa, Ni Made. 2014.

PanganTradisional Khas Gianyar. Denpasar: Udayana Iniversity Press.

\section{Website}

https://groups.google.com/d/msgid/gastronmi_i ndonesia diakses pada tanggal11/01/2016

indraket@gmail.com diakses pada tanggal 27/11/2016. 